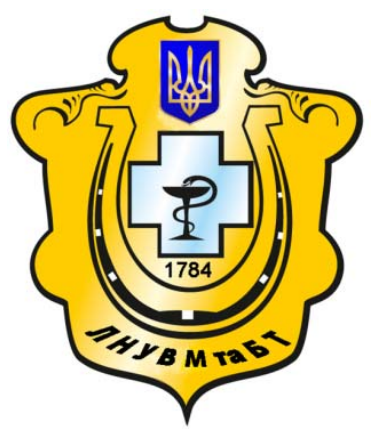

Науковий вісник Львівського національного університету ветеринарної медицини та біотехнологій імені С.3. Гжицького

Scientific Messenger of Lviv National University of Veterinary Medicine and Biotechnologies named after S.Z. Gzhytskyj

doi:10.15421/nvlvet7039

ISSN 2413-5550 print

ISSN 2518-1327 online

$\underline{\text { http://nvlvet.com.ua/ }}$

УДК 636.1/.09:614.4::612.6

\title{
Аналіз порушень репродукційної функції кобил за латентного перебігу ринопневмонії
}

\author{
М.I. Кривда \\ kryvdaznaeu@gmail.com \\ Житомирський начіональний агроекологічний університет, \\ Старий бульвар, 7, м. Житомир, 10002, Україна
}

Отримання здорового молодняку часто є головною запорукою ефективного ведення тваринництва, зокрема в конярстві. Сучасні кінні господарства зустрічаються з такими порушеннями репродуктивної функції, як самовільне переривання жеребності, народження слабкого молодняку, а також нерезультативні осіменіння та відсутність охоти у кобил (перегули). Це характерно, в першу чергу, для господарств стаціонарно неблагополучних щоодо герпесвірусних інфекцій різних munis.

Метою проведеної дослідної роботи став аналіз виявлених патологій репродукиії та визначення етіології їх прояву шляхом аналізу гематологічних показників кобил для дослідного кінного господарства, стаціонарно неблагополучного щодо вірусу ринопневмонії коней та лептоспірозу. Аналіз гематологічних показників дозволив провести паралелі між відхиленнями циитологічних та біохімічних показників крові кобил від норми та проявом патологій репродукиї з врахуванням серологічних даних інфікування збудниками ринопневмонії та лептоспірозу. Отриманні в ході вивчення данні дозволили підтвердити герпесвірусну етіологію абортів та народження слабкого молодняку; необхідність неспецифічної стимуляції кобил, направленої на підвищення загальної резистенції без застосування імуностимуляторів, та раціональність подальщих детальних досліджень мікробіологічної контаміначії статевих шляхів кобил, у яких реєструвались нерезультативні осіменіння та перегули.

Ключові слова: кобили, порушення репродукиії, гематологічні показники, герпесвірус коней першого типу (ринопневмонія).

\section{Анализ нарушений функции репродукции у кобыл при латентном течении ринопневмонии}

\author{
М.И. Кривда \\ kryvdaznaeu@gmail.com
}

Житомирский национальный агроэкологический университет, Старый бульвар, 7, г. Житомир, 10002, Украина

Получение здорового молодняка часто является основой эффективного ведения скотоводства, в частности коневодства. Современные конные хозяйства встречаются с такими нарушенияли репродуктивной функции, как самопроизвольное прерывание жеребости, рождение слабого молодняка, а также нерезультативные осеменения и отсутствие охоты у кобыл (перегулы). Это характерно, в первую очередь, для хозяйств, стационарно неблагополучных по отношению к герпесвирусным инфекциям разных типов.

Целью проведенной исследовательской работы стал анализ обнаруженных патологий репродукции и определение этиологии их проявлений методом анализа гематологических показателей кобыл для исследовательского хозяйства, стационарно неблагополучного по отношению к ринопневмонии и лептоспирозу. Анализ гематологических показателей позволил провести параллели между отклонениями ицитологических и биохимических показателей крови кобыл от нормы и проявлинием патологий репродукции с учётом серологических данных инфицирования возбудителями ринопневмонии и лептоспиро-

\section{Citation:}

Kryvda, M. (2016). Analize of the disorders in reproductive function of mares with latent form of the herpesvirus tipe-1. Scientific Messenger LNUVMBT named after S.Z. Gzhytskyj, 18, 3(70), 167-170. 
за. Данные, полученные в ходе исследований, позволили подтвердить герпесвирусную этиологию абортов и рождения слабого молодняка; необходимость неспецифической стимуляции кобыл, направлений на повыщение общей резистенции без использования иммуностимуляторов, и рациональность дальнейших детальных исследований микробиологической контаминации половых путей кобыд, у которых регистрировались нерезультативные осеменения и перегуль.

Ключевые слова: кобыль, нарушение репродукиии, гематологические показатели, герпесвирус лошадей первого типа (ринопневмония).

\title{
Analize of the disorders in reproductive function of mares with latent form of the herpesvirus tipe- 1
}

\author{
M. Kryvda \\ kryvdaznaeu@gmail.com
}

\begin{abstract}
Zhytomyr national agroecological university, Staryj Boulevard, 7, Zhytomyr, 10002, Ukraine
\end{abstract}

\begin{abstract}
We are living in time of economic regulation in all spheres. If you want to be in stream you need be economic effective. The main key to effective management in stock-breeding and also in horse-breeding is getting healthy cattle. But this is possible not in all case. Nowadays horse farms meet with such reproductive disorders as abortions, birth of weak foals and ineffective inseminations, sexual without (deregulation). Fast of all it's real especially for house-farms which are permanently unfortunate about herpesvirus infections of different types. That's why we made monitoring of gynecological disorders in such horse farm to test the part of them happened in it. In parallel were tested hematological indexes of healthy mares and those who had reproductive disorders. Analyze of reproductive pathology and establish its etiology in testing of hematological indexes of farm mares, permanently troubled about horses herpesvirus type one and type two and leptospirosis, became the aim of the research. Analysis of hematological indexes allowed making parallels between declination of cytological and biochemical blood indexes of the mares and reproductive pathologies taking into consideration serological results to herpesvirus and leptospirosis. Testing results allow us to make some conclusions. So was proved rhinopneumonia's etiology in abortion and birth of weak foals, what were happened in the experimental horse farm. Most of the tested mares need non-specific stimulation of immune system (overall resistance), but without using immunostimulations. Because of this medicaments animal's immunitet become exhaustion. We could not make concrete consequences about cause of occurrence ineffective insemination and deregulation mares. That's why it is rational to study microbial contamination of the genital tract of mares with ineffective insemination and deregulation in further. It's known that genital tract's excessive bacterial contamination often can be a reason of gynecological disorders. Bacterial disbiosis often can be consequences of untimely birth (foalbirth) and in same time it lowering the possibilities for conception. This case needs more attention because of common persistence of hors herpesvirus and bacterial contaminators. They make favourable conditions to progressive for each other in way of decrease of immune protection of horse body. Looking in this our research is topicality, actual nowadays.
\end{abstract}

Key words: mare abuse reproduction, hematologic indexes, herpesvirus tipe-1 of horses.

\section{Ветуп}

Захворюваність тварин та прояв патологічних станів у них часто пов'язують із специфічними факторами, проводячи діагностику, спираючись на можливість виявлення певного збудника (збудників). Не дивлячись на провідний закордонний досвід, аналіз патології як мультифакторного процесу відбувається рідко не лише на теренах нашої держави, але й СНГ, загалом (Makarov, 2005). Розвиток монофакторного захворювання чітко підпорядковується постулатам тріади Р. Коха, формуючи причинно-наслідковий зв'язок «збудник - господар (тварина) - захворювання». В такому разі діють динамічні, лінійні зв'язки, які базуються на, переважно, естафетній передачі збудника (Lashkevich et al., 2002; Dzhupina, 2002). В той самий час, для великих тваринницьких комплексів особливо небезпечними залишаються умовнопатогенні (убіквінтарні) збудники, що здатні викликати захворювання (часто з безсимптомним перебігом) лише при поєднанні ряду як екзогенних, так і ендогенних факторів (Makarov, 2005, 2008). Тому при виявленні патологій, зокрема і репродуктивної системи, необхідний комплексний підхід, що включатиме аналіз етіологічного фактору як специфічної, так i убіквінтарної природи.
В умовах субклінічного перебігу, як вірусних, так і бактеріальних інфекцій (спричинені умовнопатогенними агентами), прогресуюча патологія часто залишається недіагностованою через відсутність клінічних проявів, або сумісний перебіг декількох інфекцій, чи поєднання субклінічних інфекцій з інвазіями. Слід зазначити, що навіть прихована персистенція умовно-патогенних агентів в сечостатевій системі знижує шанси на результативне осіменіння та несе потенційну загрозу перериванню жеребності (Kira, 2001; Bajramova, 2001; Begas et al., 2012).

Метою дослідження було вивчення проявів та визначення причинності патологій репродукції в кінному заводі.

\section{Матеріал і методи досліджень}

Проведено аналіз виявленних патологій репродукції (переривання жеребності, народження слабкого молодняку, нерезультативні осіменіння, відсутність охоти). Для з'ясування причини прояву небажаних ефектів в процесі відтворення, здійснено комплексний аналіз за рядом факторів: моніторинг серопозитивності кобил щодо герпесвірусу коней (ГВК) першого та другого типів в реакції дифузної преципітації в гелі, а також лептоспірозу в реакції мікроаглютинації; ви- 
вчення гематологічних показників. Для контролю в ході проведення дослідження сформовано 3 групи тварин: першу складали кобили серонегативні щодо ГВК двох типів та лептоспірозу; другу - конематки серонегативні щодо лептоспірозу та серопозитивні щодо ГВК двох типів; третю - серопозитивні щодо ГВК та лептоспірозу. У всіх кобил контрольних груп за всі роки спостереження не було зафіксовано патологій репродуктивної сфери.

\section{Результати та їх обговорення}

Моніторинг гінекологічних патологій протягом трьох років показав, що в господарстві спостерігаються поодинокі прояви абортів (2,5\%), народження слабкого молодняку (4,3\%), але наймасовіше виявляються прециденти нерезультативних осіменінь $(17,3 \%)$ та випадки відсутності охоти у кобил $(17,3 \%)$. При цьому клінічний огляд кобил не виявляв відхилень від норми.

Результати серологічного аналізу відібраних зразків сироватки крові засвідчують, що переважна більшість кобил 3 проявами гінекологічних патологій були серопозитивними щодо лептоспірозу (68\%) та ГВК-1 (84\%) і ГВК-2 (62\%), але клінічних симптомів прояву цих інфекцій не спостерігалось. Лише 4,4\% від досліджених тварин були серонегативними до всіх досліджуваних збудників. Така сумісна персистенція, за даними світових вчених, створює замкнене коло, коли субклінічне носійство герпесвірусів створює передумови для зниження загальної резистенції макроорганізму та сприяє захворюваності не лише на лептоспіроз, але й виникненню неспецифічних патологій та нестандартних перебігів при приєднанні неспецифічних збудників. Але і бактеріальні агенти сприяють активації ГВК.

Аналіз цитологічних показників виявив ряд закономірностей, зокрема низький рівень гематокриту у тварин з гінекологічними патологіями на ряду з вмістом еритроцитів та лейкоцитів, переважно, в межах норми (табл. 1). Серед кобил, що абортували, відмічається тенденція до достовірного зниження в крові кількості лейкоцитів $(5,0-6,5$ Г/л). Такі показники можуть бути наслідком багатьох чинників, зокрема вірусних захворювань, збудники яких проявляють тропність до лімфоїдних клітин. Також у цих тварин відмічено низький вміст загального білку в сироватці крові (52,5 - 56,8 г/л) та нормоцитарна гіпохромна (за кольоровим показником) анемія, що свідчить про наявність дрібних форм клітин крові (переважно еритроцитів). Це підтверджується також низьким вмістом гемоглобіну (гіпохромна анемія).

Таблиияя 1.

Цитологічні та біохімічні показники крові кобил господарства

\begin{tabular}{|c|c|c|c|c|c|c|c|}
\hline \multirow{2}{*}{$\begin{array}{l}\text { № } \\
\text { П/ா }\end{array}$} & \multirow{2}{*}{$\begin{array}{c}\text { Виявлена пато- } \\
\text { логія }\end{array}$} & \multicolumn{6}{|c|}{ Досліджені показники } \\
\hline & & $\begin{array}{c}\text { Гемато- } \\
\text { крит, \%/л }\end{array}$ & $\begin{array}{c}\text { Еритроцити, } \\
\text { Т/л }\end{array}$ & $\begin{array}{c}\text { Лейкоцити, } \\
\text { Г/л }\end{array}$ & $\begin{array}{c}\text { Гемоглобін, } \\
\text { г/л }\end{array}$ & $\begin{array}{l}\text { Колірний } \\
\text { показник }\end{array}$ & $\begin{array}{c}\text { Заг. білок, } \\
\text { г/л }\end{array}$ \\
\hline 1. & $\begin{array}{c}\text { Слабонародж } \\
\text { приплід }\end{array}$ & $\begin{array}{l}35,6^{1,2^{*}, 3^{* *}} \\
\quad \pm 4\end{array}$ & $\begin{array}{c}6,4^{1,2^{* *}} \\
\pm 1,2\end{array}$ & $7,8 \pm 2,3$ & $93^{1,2^{* *}} \pm 20$ & $\begin{array}{c}0,43^{1 * *, 2^{*}} \\
\pm 0,04\end{array}$ & $60,1 \pm 3,6$ \\
\hline 2. & Аборт & $\begin{array}{c}35,4^{1,2,3^{*}} \\
\pm 3,5\end{array}$ & $6,6 \pm 1$ & $5,5^{2^{*}, 3^{* *}} \pm 0,7$ & $\begin{array}{c}102,1^{1,2^{*}} \\
\pm 13,4\end{array}$ & $0,47 \pm 0,04$ & $\begin{array}{c}56^{1^{* *}, 3^{*}} \\
\pm 2,8\end{array}$ \\
\hline 3. & $\begin{array}{c}\text { Не прийшли в } \\
\text { охоту }\end{array}$ & $\begin{array}{c}38,1^{1,2^{* *}} \\
\pm 6\end{array}$ & $7,0 \pm 1$ & $7,2 \pm 1,4$ & $\begin{array}{c}104,1^{1,2^{*}} \\
\pm 19,5\end{array}$ & $0,45 \pm 0,08$ & $61,1 \pm 7,3$ \\
\hline 4. & $\begin{array}{c}\text { Прохолостілі } \\
\text { конематки }\end{array}$ & $\begin{array}{c}39,1^{1^{*}} \\
\pm 6\end{array}$ & $7,0 \pm 1$ & $\begin{array}{c}7,0^{3 * *} \\
\pm 1\end{array}$ & $\begin{array}{l}106^{1,2^{* *}} \\
\pm 22,7\end{array}$ & $0,46 \pm 0,08$ & $61,9 \pm 8$ \\
\hline 5. & $\begin{array}{c}\text { Контроль, } \\
\text { група } 1\end{array}$ & $44,8 \pm 3,6$ & $7,7 \pm 0,7$ & $7,7 \pm 1,8$ & $130 \pm 16,5$ & $0,51 \pm 0,05$ & $64,0 \pm 5,6$ \\
\hline 6. & $\begin{array}{l}\text { Контроль, } \\
\text { група } 2\end{array}$ & $44,2 \pm 3$ & $7,7 \pm 0,8$ & $7,7 \pm 1$ & $131,2 \pm 15,7$ & $0,51 \pm 0,04$ & $61,9 \pm 6$ \\
\hline 7. & $\begin{array}{l}\text { Контроль, } \\
\text { група } 3\end{array}$ & $41,4 \pm 1,3$ & $6,6 \pm 0,5$ & $8,2 \pm 1,8$ & $101,6 \pm 8,6$ & $0,46 \pm 0,04$ & $65,4 \pm 4,6$ \\
\hline & Норма & $42-59$ & $6-10,0$ & $6,8-8,5$ & $100-160$ & $0,8-1,05$ & $60-80$ \\
\hline
\end{tabular}

$1,2,3$ - нумерація контролів. ${ }^{*}-\mathrm{p} \leq 0,01 ; * *-\mathrm{p} \leq 0,05$.

Про недостатній вміст гемоглобіну в одому еритроциті свідчить і низький кольоровий показник. Слід зазначити, що цей похідний показник у жодної з досліджених тварин не досягав норми, навіть у тих, у яких вміст гемоглобіну в крові був на високому рівні. Така ситуація може стати наслідком нестачі вітамінів групи В, а також фолієвої кислоти наприкінці холодної пори року, анемії в термінальні строки жеребності та в період після вижереблення.

В контрольній групі № 3, тварини якої є серопозитивними щодо ГВК-1 та ГВК-2, а також лептоспірозу, але без зафіксованих в роки спостереження гінекологічних патологій, мали, переважно, показники ниж- чі, порівнюючи з двома іншими контрольними групами (табл. 1). Виняток склали лише два показника: кількість лейкоцитів в крові та вміст загального білку в сироватці крові досліджених кобил. Це явище $є$ цілком закономірним і засвідчує стабільність функціонування імунної системи: як клітинного імунітету, так і гуморального. Знижений рівень еритроцитів та гемоглобіну, низький колірний показник $є$ наслідком функціонування імунної системи. вироблення значної кількості інтерлейкінів та інтерферону, які, як відомо, пригнічують еритропоез та метаболізм заліза. Низькі показники кількості еритроцитів, вмісту гемоглобіну 
також свідчать про поступове виснаження організму кобил.

В ході аналізу досліджених гематологічних показників було виявлено ряд тварин, у яких спостерігали порушення процесу утворення кров'яного згустку низький рівень ретракції. Такі кобили потребують посиленої уваги та проведення курсу детоксикаційної терапії, за результатами якої буде дана відповідь про можливість та доцільність їх подальшого використання.

\section{Висновки}

При співставленні клінічного огляду кобил, їх гематологічних, біохімічних і серологічних показників, а також даних щодо прояву гінекологічних патологій була доведена причинність збудника ринопневмонії у прициндентах переривання жеребності в господарстві та народження слабкого молодняку.

Аналіз показників тварин серопозитивних щодо ГВК-1 та лептоспірозу засвідчив неодмінну потребу загальної стимуляції тварин, але не за допомогою імуностимуляторів, що будуть додатково виснажувати потенціал організму, а забезпеченням збалансованої годівлі, вітамінотерапії та ретроспективного контролю серологічного статусу щодо ринопневмонії та його корекції.

3 групами тварин за латентного перебігу ринопневмонії, які не приходять в охоту та перегулюють, необхідна детальна робота та додаткове дослідження. У кобил цих груп доцільно перевірити мікробіологічний статус статевих шляхів на предмет виявлення агентів, здатних провокувати розвиток бактеріального вагінозу, що може стати причиною нерезультативних осіменінь та перегулів.

\section{Бібліографічні посилання}

Makarov, V.V. (2005). Faktornye bolezni i prichinnost' v infekcionnoj patologi. Veterinarnaja patologija. 3, 412 (in Russian).

Lashkevich, V.A. Koroleva, G.A., Lukashev, A.N. (2002). Sovremennye dokazatel'stva infekcionnoj jetiologii boleznej i postulaty Koha. Zhurn. mikrobiol. 6, 117-121 (in Russian).

Dzhupina, S.I. (2002). Jepizooticheskij process i ego kontrol' pri faktornyh infekcionnyh boleznjah. M. (in Russian).

Makarov, V.V. (2008). Sapronozy, faktornye i opportunisticheskie infekcii ( $\mathrm{k}$ istorii jetiologicheskih vozzrenij $\mathrm{V}$ otechestvennoj jepidemiologii i jepizootologii). Veterinarnaja patologija. 1, 7-17 (in Russian).

Kira, E.F. (2001). Bakterial'nyj vaginoz. SPb.: NevaLjuks (in Russian).

Begas, V.L., Galatjuk, O.Je., Radzyhovs'kyj, M.L., Antonjuk, A.A. (2012). Epizootychnyj monitoryng ta profilaktyka zaraznyh hvorob konej. Naukovyj visnyk veterynarnoi' medycyny. 9 (92), 33-36. (in Ukrainian).

Bajramova, G.R. (2001). Bakterial'nyj vaginoz. Ginekologija. 3, 2, 52-54 (in Russian).

Стаття надійшла до редакиії 17.09.2016 